\title{
“PSEUDORHEUMATOID” NODULES IN CHILDREN
}

\author{
John Pournaras, Greece, and A. A. M. Gibson, Glasgow, Scotland \\ From the Royal Hospital for Sick Children, Glasgow'
}

Subcutaneous nodules which are characterised by central fibrinoid necrosis, surrounded by histiocytes and fibroblasts are traditionally considered to be manifestations of rheumatoid arthritis or rheumatic fever. In recent years, however, cases in which such nodules appeared in otherwise healthy children have been reported.

Beatty (1959) reported nine children, aged between eleven days and nine years, with isolated nodules located on the scalp, ulnar aspect of the forearm, palm and dorsum of the foot, who had no manifestations of rheumatic disease. He postulated that these lesions represented an unusual reaction to trauma. Draheim, Johnson and Helwig (1959) reported fifty-seven children between three and six years old with subcutaneous nodules. One patient developed rheumatic fever but none had rheumatoid arthritis. Twenty-five per cent gave a history of injury. They suggested a relationship between the nodules and allergy. Taranta (1962) described nodules in a six-year-old girl, histologically identical to those seen in rheumatic disease; he considered an altered reaction to trauma as a possible cause. Altman and Caffrey (1964) reported similar nodules in two children without systemic disease. Mesara, Brody and Oberman (1966) introduced the term "pseudorheumatoid", referring to subcutaneous nodules histologically resembling rheumatoid nodules but without evidence of systemic disease; they published ten cases in children and two in adults. None of them had collagen disease or developed it during a period of observation of from one to seventeen years, but after excision seven showed recurrent nodular formations. The authors could not explain the etiology, nor could they differentiate the nodules with certainty from rheumatoid nodules,

TABLE I

Clinical Details in Eight Patients

\begin{tabular}{|c|c|c|c|c|c|c|c|}
\hline $\begin{array}{c}\text { Case } \\
\text { number }\end{array}$ & $\underset{\text { (years) }}{\text { Age }}$ & Sex & Site & $\begin{array}{l}\text { Pre-operative } \\
\text { diagnosis }\end{array}$ & Treatment & Recurrence & Follow-up \\
\hline 1 & 31 & Male & Occiput & ? Rheumatic nodules & Sulphadiazine & Yes & $\begin{array}{l}11 \text { years } \\
\text { No nodules }\end{array}$ \\
\hline 2 & 2 & Female & $\begin{array}{l}\text { Upper tibia } \\
\text { (front) }\end{array}$ & Nodules & Excision & No & $\begin{array}{c}1 \text { year } \\
\text { No nodules }\end{array}$ \\
\hline 3 & 2 & Female & $\begin{array}{l}\text { Tibia (front) } \\
\text { Foot (dorsum) }\end{array}$ & $\begin{array}{l}\text { Rheumatic nodules or } \\
\text { periosteal haematomata }\end{array}$ & Sulphadiazine & Yes & $\begin{array}{l}10 \text { years } \\
\text { No nodules }\end{array}$ \\
\hline 4 & 23 & Female & $\begin{array}{l}\text { Both tibiae } \\
\text { (dorsum) }\end{array}$ & $\begin{array}{l}\text { Subcutaneous } \\
\text { nodules }\end{array}$ & Penicillin & Yes & $\begin{array}{l}7 \text { years } \\
\text { No nodules }\end{array}$ \\
\hline 5 & $4 !$ & Female & Tibia (front) & $\begin{array}{c}\text { Organising } \\
\text { haematomata }\end{array}$ & Excision & No & $\begin{array}{l}2 \frac{1}{2} \text { years } \\
\text { No nodules }\end{array}$ \\
\hline 6 & 11 & Female & Foot (dorsum) & $\begin{array}{l}\text { Encysted } \\
\text { foreign bodies }\end{array}$ & Excision & Yes & $\begin{array}{l}2 \text { years } \\
\text { No nodules }\end{array}$ \\
\hline 7 & 4 & Male & Foot (dorsum) & Hamartoma & Excision & No & $\begin{array}{l}9 \text { months } \\
\text { No nodules }\end{array}$ \\
\hline 8 & $2 \frac{1}{2}$ & Male & $\begin{array}{l}\text { Upper tibia } \\
\text { (front) }\end{array}$ & Bursitis & Excision & No & $\begin{array}{l}3 \text { months } \\
\text { No nodules }\end{array}$ \\
\hline
\end{tabular}


but they found slight microscopic differences. In "pseudorheumatoid" nodules more florid proliferation of histiocytes, a lesser degree of peripheral collagenisation and less central fibrinoid necrosis were seen. Burrington (1970) reviewed ten cases with subcutaneous nodules in children between seven days and nine years old, located over the tibia, dorsum of the foot, palm, occiput or scalp. They were followed for from six months to nineteen years and none developed collagen disease. There was no recurrence.

\section{MATERIAI,}

In the last twenty years thirteen children attending the Royal Hospital for Sick Children, Glasgow, had nodules excised which showed histological similarity to rheumatoid nodules and were not accompanied by any other pathological sign. Eight of these patients have been re-examined.

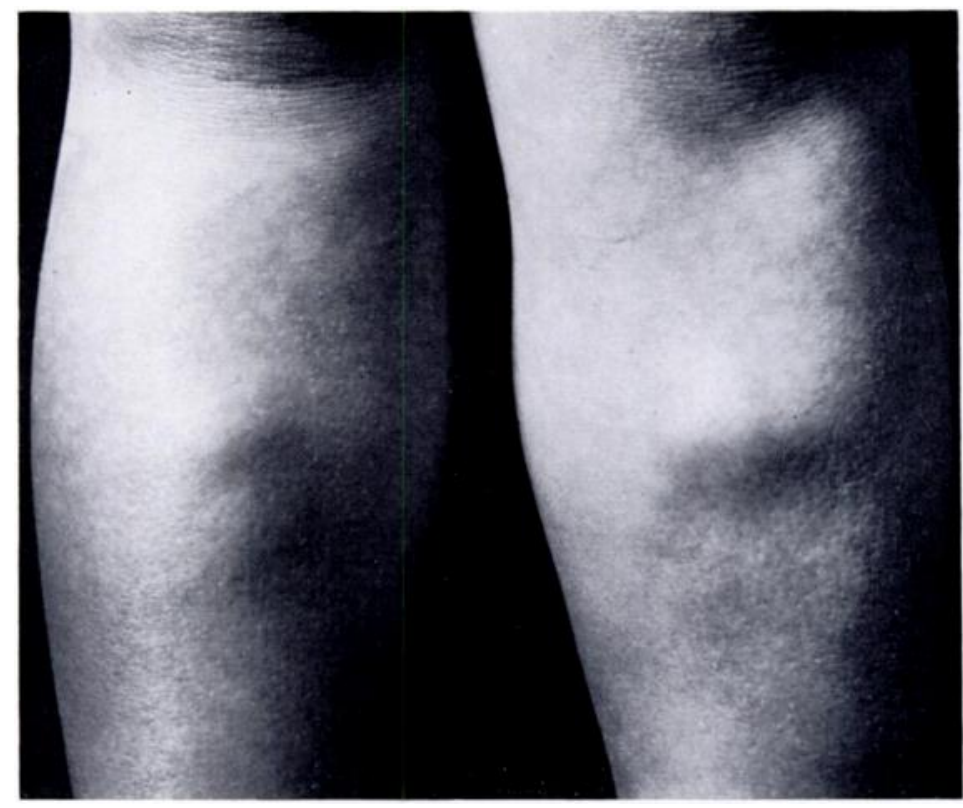

FIG. 1

Girl aged 23 years with subcutaneous nodules at the front of both shins of three months' duration.

Clinical features-The children were from two to eleven years old, the majority less than five years. Five were girls and three boys (Table I). The nodules were found on the front of the tibia, the dorsum of the foot or the occiput. In two children the lesions were multiple.

In the five cases in which follow-up was not possible, the age ranged from one and a half to six and a half years: three were girls and two boys. The lesions were located on the scalp, temple, knee, fingers, hypothenar eminence or tibia. In two, the lesions were multiple.

On first attendance at the hospital, the children had firm subcutaneous nodules 3 to 30 millimetres in diameter attached to the deep fascia or to the sheath of a tendon (Fig. 1). None of them was tender. They had been present for one to eight months. All were increasing in size. There was a history of trauma in one. Radiographs showed a local soft-tissue swelling (Fig. 2).

No patient showed any evidence of systemic disease. One child gave a throat swab positive for haemolytic streptococcus; in all the others all investigations were negative. 
Treatment In five cases the nodules were excised and in three biopsy was performed. Of the three children subjected to biopsy, two received sulphadiazine for six and twelve months and one received a prolonged course of penicillin.

Follow-up In five children the follow-up was from two to eleven years (Table I). One child showed recurrence after excision and three, in whom only biopsy was performed, also had

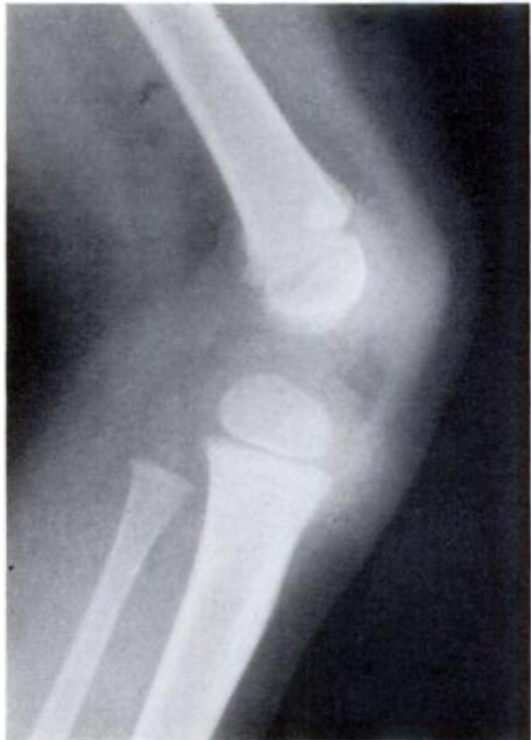

FIG. 2

Lateral radiograph of a boy aged 2.1 years with subcutaneous nodules over the anterolateral aspect of the patellar tendon. Note the localised soft-tissue swelling. nodules at two years, but in all these four the nodules had disappeared when the patients were seen at final review.

One child after six years developed erythema nodosum, but no sign of streptococcal infection was discovered. In no patient were signs of rheumatoid arthritis or rheumatic fever found when the children were re-examined.

\section{PATHOLOGY}

The macroscopic appearance of the lesion is not specific. Small poorly circumscribed foci of fibrous tissue may be distinguished in the subcutaneous fat, or a single indurated mass, grey-white in colour, may merge with the surrounding normal subcutaneous tissue. Underlying muscle tissue was involved in two cases in which the nodule was on the scalp.

Histological examination shows a lesion which is multifocal in nature (Fig. 3). Each focus consists of a central area of necrosis of the connective tissue surrounded by a zone of reactive proliferation of histiocytes and fibroblasts which merges into mature connective tissue. The necrotic centre consists sometimes of acellular poorly-staining debris but often there is an irregular network of eosinophilic material with the staining properties of fibrin-so-called fibrinoid necrosis (Fig. 4). In larger lesions the necrotic area may be irregular in outline, and with the removal of necrotic material a central cleft may be formed. The histiocytes and fibroblasts are orientated more or less radially around the necrotic centre to give a palisading arrangement. A mild infiltration of lymphocytes is usual among the histiocytes; eosinophils were prominent in two cases. Inflammatory cells are present also in the surrounding connective tissue, mainly of perivascular distribution. Proliferation of the capillaries with swelling of the endothelial cells is a constant feature.

These lesions are indistinguishable histologically from the subcutaneous nodules of rheumatoid arthritis or rheumatic fever.

\section{DISCUSSION}

In only two cases was the diagnosis of rheumatoid or rheumatic nodules suspected before biopsy. In all the others only the report of the pathologist brought attention to this possibility. This was due to the fact that there were no features which would suggest collagen disease.

In only one case was there a history of trauma. One other patient gave a positive streptococcal throat swab and a third developed erythema nodosum. While the suggestion of trauma as a causative factor is not accepted, the possibility of a special reaction to streptococcal infection cannot be completely excluded.

Five children have been watched for over two years and have remained normal. We therefore see no reason to treat patients presenting with these nodules by long-term therapy of any kind, if rheumatoid arthritis and rheumatic fever have been excluded by clinical and laboratory means. 


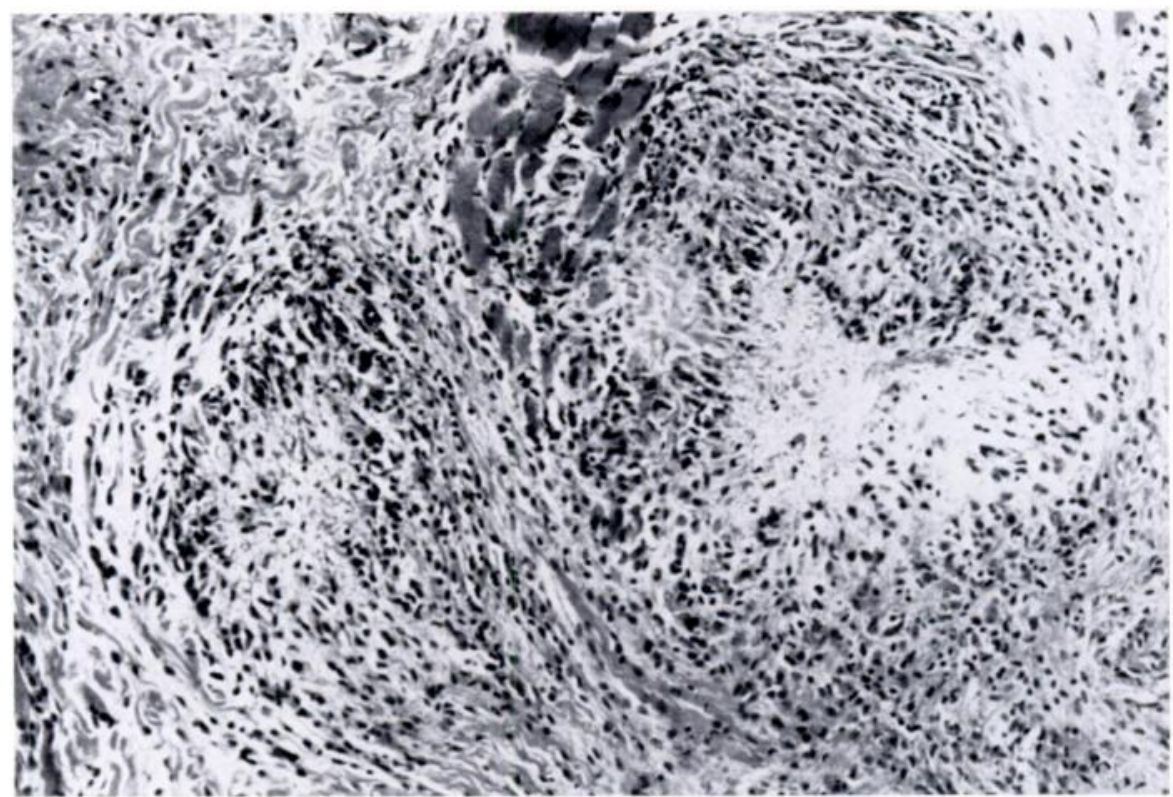

FIG. 3

Histological section from a nodule on the scalp, showing a characteristic lesion involving underlying muscle.

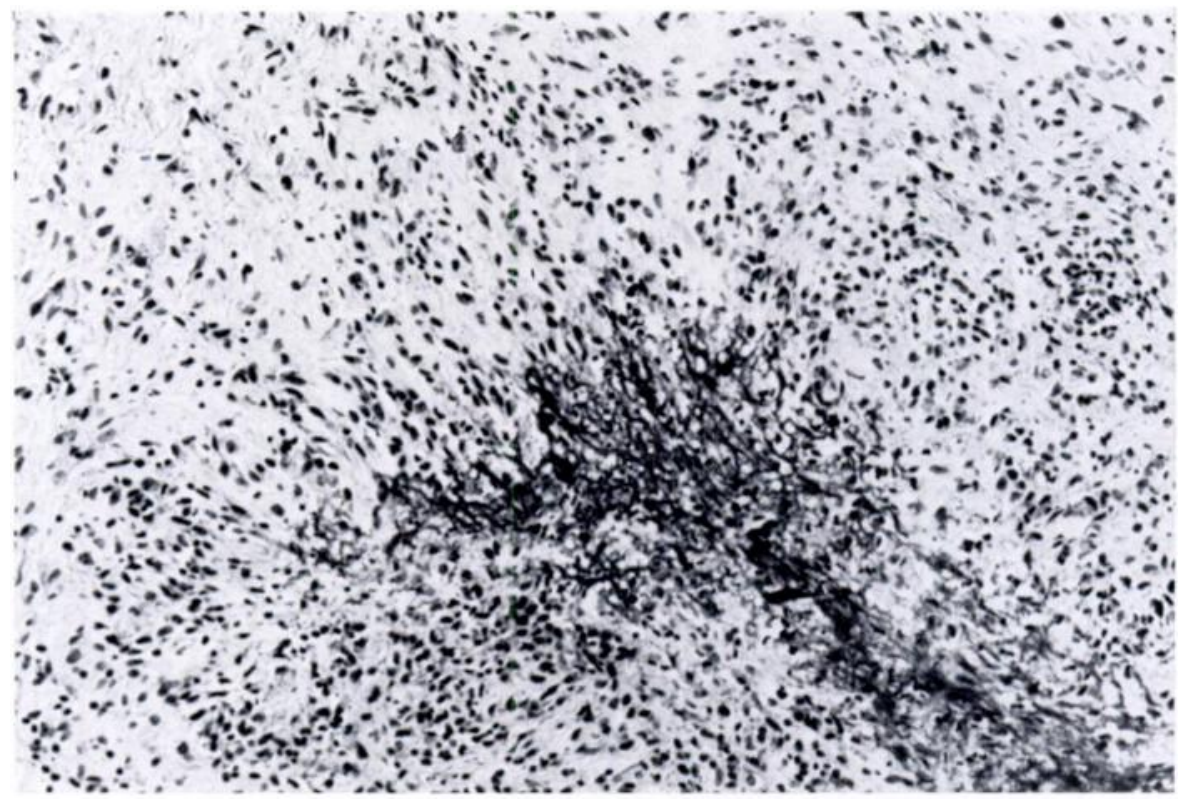

Fig. 4

Central area of fibrinoid necrosis surrounded by proliferating histiocytes and fibroblasts. 


\section{SUMMARY}

1. Thirteen cases of "pseudorheumatoid" nodules are presented. Eight of these have been observed for three months to eleven years.

2. Histologically the nodules were identical to those that may be associated with rheumatoid arthritis or rheumatic fever.

3. No evidence of systemic disease was found.

4. The etiology is not clear but the prognosis is good.

We wish to thank Mr N. J. Blockey for his advice and criticism, and Mr D. A. Macpherson, Mr M. G. H. Smith, Mr J. F. R. Bentley and Mr S. L. Mann for access to their patients.

\section{REFERENCES}

Altman, R. S., and Caffrey, P. R. (1964): Isolated Subcutaneous Rheumatic Nodules. Pediatrics, $34,869$.

Beatty, E. C. (1959): Rheumatic-like Nodules Occurring in Nonrheumatic Children. Archives of Pathology, 68, 154.

Burrington, J. D. (1970): "Pseudorheumatoid" Nodules in Children. Pediatrics, 45, 473.

Draheim, J. H., Johnson, L. C., and Helwig, E. B. (1959): A Clinicopathologic Analysis of "Rheumatoid" Nodules Occurring in 54 Children. American Journal of Pathology, 35, 678.

Mesara, B. W., Brody, G. L., and Oberman, H. A. (1966): "Pseudorheumatoid" Subcutaneous Nodules. American Journal of Clinical Pathology, 45, 684.

TARANTA, A. (1962): Occurrence of Rheumatic-like Subcutaneous Nodules without Evidence of Joint or Heart Disease. New England Journal of Medicine, 266, 13. 